\title{
The Energy Charter Treaty, Frivolous Claims and the Looming Threat of Investor-state Dispute Settlement: Any Hope from the EU's Modernisation Proposal?
}

\author{
Oskari Vaaranmaa* \\ DOI: $10.21827 /$ GroJIL.8.2.270-287
}

\begin{abstract}
Keywords
INTERNATIONAL INVESTMENT LAW; FRIVOLOUS CLAIMS; ENERGY CHARTER TREATY
\end{abstract}

\begin{abstract}
The system of investor-state dispute settlement ('ISDS') is being increasingly perceived as a hindrance to States' efforts to regulate against climate change. A potential scenario for this concern is that, as more robust environmental regulation is made, investors who have been adversely impacted in the fossil fuel sector, will threaten to sue States under international investment agreements ('IIAs'). This is not just a hypothetical concern. Recently, German energy company Uniper has threatened to take legal action against Netherlands for its coal phase out plan. Against this backdrop, contracting parties to the Energy Charter Treaty ('ECT'), the world's most widely invoked IIA, are attempting to modernise the ECT to, inter alia, better accommodate States' right to regulate. Amongst the proposed amendments is the inclusion of a provision on frivolous claims, under which claims that are found to be legally untenable can be summarily dismissed. This paper will put forward the argument that, based on existing jurisprudence on frivolous claims and the European Union's ('EU') proposal, the provision will likely be too weak to effectively address the types of cases that ECT contracting parties are concerned about. In other words, as far as the prevailing line of jurisprudence is concerned, the vast majority of the anticipated cases will be too legally and factually complicated to be addressed on a summary basis. That is unless Tribunals interpreting the modernised ECT make a conscious effort to broaden the provision's applicability to more complex cases.
\end{abstract}

\section{Introduction}

Following the collapse of the Soviet Union, Western European States were eager to tap into the vast energy resources of Eastern Europe. ${ }^{1}$ Equally, in the words of Hobér, the latter States were 'rich in energy but in great need of investment'. ${ }^{2}$ The product of these

\footnotetext{
* The author is a recent LLM graduate from the University of Groningen. He wrote his thesis on the topic of frivolous claims in the ICSID system (Research question: To what extent has a jurisprudence constante emerged on the phrase 'manifestly without legal merit' under ICSID Arbitration Rule 41(5)?). The following paper is based on an adaptation of this thesis. This article was selected for publication and finalised before the author's selection to the traineeship programme of the European Commission. Thus, the content of the article is based exclusively on publicly available material, and the views, opinions, assumptions and analyses expressed therein belong solely and unequivocally to the author. Email: oskari.vaaranmaa@gmail.com

1 Andrei Konoplyanik and Thomas Wälde, 'The Energy Charter Treaty and its Role in International Energy' (2006) 24 Journal of Energy \& Natural Resources Law 523, 524-530 and 556-557.

2 Kaj Hobér, 'Investment Arbitration and the Energy Charter Treaty' (2010) 1 Journal of International Dispute Settlement 153, 154.

This work is licensed under the Creative Commons Attribution-NonCommercial-NoDerivatives 4.0 International License. To view a copy of this license, visit http://creativecommons.org/licenses/by-nc-nd/4.0/.
} 
two wants was the ECT, which is now the most widely invoked instrument in investorstate arbitration, representing a fifth of over 1000 cases. $^{3}$

Under Part III of the ECT, each contracting party pledges to protect investments made by investors from every other contracting party. ${ }^{4}$ Thus, the ECT seeks to ensure that if foreign investments are frustrated by, for instance, discrimination or expropriation, the investor is able to take legal action against the host State (i.e. the State in which the investment is made) through investment arbitration. ${ }^{5}$ Although the investor and State must seek to amicably settle the dispute, there is no subsequent need to resort to the domestic courts of the host State, as international arbitration is immediately available through article $26(4){ }^{6}$

However, more recently, the ease at which legal proceedings can be initiated against States has become problematic to ECT contracting parties. One of the general anxieties is that as States attempt to implement environmental legislation, they risk facing ISDS procedures started by energy investors. More specifically, since such regulation may result in economic damages to the investment, the investor may have grounds to allege various breaches of Part III of the ECT. Consequently, the fear of facing a long, costly arbitration leads to so-called 'regulatory chill'. Kyla Tienhaara, who has written extensively on this topic, describes the concept in the following succinct manner: 'governments will fail to regulate in the public interest in a timely and effective manner because of concerns about [ISDS]. ${ }^{7}$ It goes without saying that, in the context of climate change, States should be as free as possible to take steps against its devastating effects.

The fear of litigious investors is not unjustified. Recently, German energy company Uniper has threatened to sue the Dutch government under the ECT for the ordered closure of its Maasvlakte power plant. ${ }^{8}$ This order comes as a part of the Netherland's effort to phase out coal power by $2030 .^{9}$

From NGOs to legal professionals alike, Uniper's legal claims have come under heavy criticism. ${ }^{10}$ However, what is even more worrying is that there is strong reason to suspect that this situation will not remain the last of its kind. Indeed, research by Tienhaara and Cotula indicates that 'the ECT protects at least 51 coal plants that are at risk of stranding in a Paris-compliant scenario'. ${ }^{11}$ The scenario being referred to here is one in which States succeed in limiting the increase in average global temperature to

3 UNCTAD, 'World Investment Report 2020' (UNCTAD 2020) 111 <https://unctad.org/webflyer/world-investment-report-2020> accessed 9 November 2020.

4 Energy Charter Treaty (adopted 17 December 1994, entered into force 16 April 1998) 2080 UNTS 95 (ECT) part III.

5 ibid art 26.

6 ibid arts 26(1), 26(4); See also IISD, Exhaustion of Local Remedies in International Investment Law (IISD 2017) 16.

7 Kyla Tienhaara, 'Regulatory Chill in a Warming World: The Threat to Climate Policy Posed by Investor-State Dispute Settlement' (2017) 7 Transnational Environmental Law 1, 4.

8 Pekka Niemelä and others, 'Risky Business: Uniper's Potential Investor-State Dispute Against The Dutch Coal Ban' (EJIL:Talk!, 18 March 2020) <https://www.ejiltalk.org/risky-business-uniperspotential-investor-state-dispute-against-the-dutch-coal-ban/> accessed 9 November 2020.

9 ibid.

10 Greenpeace, 'Greenpeace to Finland's energy giant Fortum: "Walk the talk on climate"' (Greenpeace, 24 October 2019) <https://www.greenpeace.org/finland/tiedotteet/2532/greenpeace-to-finlands-energygiant-fortum-walk-the-talk-on-climate/> accessed 7 December 2020; Amandine van den Berghe and Veder M Jolie, 'Legal opinion on Uniper's legally misconceived ISDS threat to Dutch coal phase-out' (Client Earth, 27 November 2019) 1 <https://www.clientearth.org/media/dkji32cj/clientearth-letterand-analysis-regarding-the-uniper-isds-threat-ce-en.pdf $>$ accessed 8 December 2020.

11 Kyla Tienhaara and Lorenzo Cotula, Raising the Cost of Climate Action: Investor-State Dispute Settlement and Compensation for Stranded Fossil Fuel Assets (International Institute for Environment and Development 2020) 32 . 
'well below $2{ }^{\circ} \mathrm{C}$ above pre-industrial levels and to pursue efforts to limit the temperature increase to $1.5^{\circ} \mathrm{C}$ above pre-industrial levels', as provided in article 2(a) of the Paris Agreement of the United Nations Framework Convention on Climate Change. ${ }^{12}$ This raises an interesting question with regard to ECT modernisation: Is there any hope for States to prevent, or significantly reduce, the potential influx of energy-related investment arbitrations?

The short answer to this question is yes. However, whether these cases can be deemed 'frivolous' and dismissed through a summary procedure is a more complicated line of inquiry. This query accordingly is the core subject matter of this paper.

Tsai-Fang Chen defines frivolous claims as 'claims that have no real possibility of prevailing' and 'lack legal merit'. ${ }^{13}$ Intent may be present, but is not necessary. It may also be quite difficult to discern.

With regard to ECT modernisation, contracting parties have proposed to include an article to directly address such claims. One of the more influential and well-elaborated proposals comes from the European Union ('EU'). ${ }^{14}$ In light of its proposal, this paper seeks to investigate whether, in the future, claims made by litigious fossil fuel companies (such as Uniper), could be deemed frivolous, and subsequently dismissed. Throughout the rest of the paper, such hypothetical legal claims will be referred to as 'Uniper-like'. All that this phrase entails is possible cases wherein a litigious investor initiates ISDS proceedings against a State for damages that were alleged to be caused by the latter's efforts to take action against climate change.

In this paper, it will be argued that based on the current state of jurisprudence on frivolous claims, the EU's proposed article will likely be too weak to address such claims. In spite of the absence of stare decisis in investment arbitration, prior jurisprudence will provide useful guidance for this query, since the proposed article is closely based upon Arbitration Rule 41(5) of the International Centre for Settlement of Investment Disputes ('ICSID'), as well as articles 10.20.4-10.20.5 of the Dominican Republic-Central American Free Trade Agreement ('DR-CAFTA'). ${ }^{15}$ Indeed, arbitral tribunals interpreting these provisions appear to have narrowed the applicability of such provisions to a very narrow range of legally untenable cases. The obverse of this is that more complicated legal cases, similar in content and context to Uniper, will likely be too legally and factually complex to be addressed through a summary procedure. Instead, they will require full hearings.

To arrive at this conclusion, this paper will be structured as follows. Firstly, in Part II, for the sake of context, a summary of the ECT modernisation process will be provided. Then, in Part III, Uniper's legal claims will be explored. In Part IV, the EU's proposed amendments will be outlined. After this, Part V will provide a run-through of

12 Paris Agreement under the United Nations Convention on Climate Change (adopted 12 December 2015, entered into force 4 November 2016) (2015) 55 ILM 743 (Paris Agreement), art 2 (a).

13 Tsai-Fang Chen, 'Deterring Frivolous Challenges in Investor-State Dispute Settlement' (2015) 8 Contemporary Asia Arbitration Journal 61, 64-65.

14 European Commission, 'EU text proposal for the modernisation of the Energy Charter Treaty (ECT)' (European Commission, $\quad$ Brussels, 27 May 2020) $<$ https://trade.ec.europa.eu/doclib/docs/2020/may/tradoc_158754.pdf> accessed 9 November 2020.

15 ICSID Rules of Procedure for Arbitration Proceedings (adopted 25 September 1967, entered into force 1 January 1968, as amended in 2006) (ICSID Arbitration Rules) rule 41(5) available at $<$ https://icsid.worldbank.org/en/Documents/resources/2006\%20CRR_English-final.pdf > accessed 9 November 2020; Dominican Republic-Central America Free Trade Agreement (adopted 5 August 2004, entered into force 1 January 2009) art 10.20.4 (DR-CAFTA); Polonskaya, 'Frivolous Claims' (n 63) 6 . 
jurisprudence on ICSID Arbitration Rule 41(5), why it will be unhelpful to address the types of claims that ECT contracting parties are worried about, and why it may be interpreted too narrowly by Tribunals. Lastly, in Part VI, some concluding remarks will be made.

\section{ECT Modernisation: Concern over Frivolous Claims}

The modernisation of the ECT has recently concluded its third round of negotiations. ${ }^{16}$ Furthermore, the ECT Conference adopted a range of policy options which are to be discussed by the contracting parties. ${ }^{17}$ As was previously mentioned, one of these proposals concerns frivolous claims.

In the 'Decision of the Energy Charter Conference,' the concern over frivolous claims surfaces on several occasions. Albania, for instance, makes the argument that ' $[\mathrm{t}]$ he dispute settlement clause of the ECT does not provide the proper procedure/mechanism to avoid or early dismiss frivolous and unmeritorious claims. ${ }^{18}$ Furthermore, Georgia states that, in its experience, 'frivolous and unmeritorious investment cases initiated for various tactics to put pressure on the host contracting party is a serious problem. ${ }^{19}$ Indeed, this appears to be a direct reference to the 'regulatory chill'-argument. In relation to this, an extensive analysis by Moehlecke strongly suggests that less economically developed states are more prone to regulatory chill, as they tend not to possess the necessary funds to participate in lengthy, international lawsuits. ${ }^{20}$ Thus, Georgia's concerns are very much justified. Switzerland goes on to add that ' $\mathrm{t}] \mathrm{he}$ existing reference to the ICSID Rules might not suffice for the other procedures' under the ECT's arbitration clause. ${ }^{21}$

Now, to borrow the words of Georgia's representatives, the case of Uniper appears to be a textbook example of an ISDS threat used 'to put pressure on the host contracting party. ${ }^{, 2}$ For the sake of context, this paper will next outline some of Uniper's arguments. This also serves to elucidate the underlying legal complexity of such cases.

\section{Uniper's Potential Claims: 'legally misconceived'?}

Firstly, this point should be prefaced by the fact that no legal proceedings have been begun as the date of writing. Indeed, this point has been emphasised by Uniper's Finnish parent company Fortum itself. ${ }^{23}$ Be that as it may, for the sake of argument and future reference, it is worth outlining Uniper's potential arguments.

16 European Commission, 'Third Negotiation Round to Modernise Energy Charter Treaty' (European Commission, 6 November 2020) <https://trade.ec.europa.eu/doclib/press/index.cfm?id=2206> accessed 9 November 2020.

17 Energy Charter Secretariat, 'Modernisation of The Treaty' (Energy Charter Secretariat) <https://www.energychartertreaty.org/modernisation-of-the-treaty/> accessed 9 November 2020.

18 Energy Charter Secretariat, 'Decision on the Energy Charter Conference' (Energy Charter Secretariat Document CCDEC $201908 \quad$ STR, Brussels, $6 \quad$ October 2019 ) 30 <https://www.energycharter.org/fileadmin/DocumentsMedia/CCDECS/2019/CCDEC201908.pdf> accessed 8 December 2020.

19 ibid.

20 Caroline Moehlecke, 'The Chilling Effect of International Investment Disputes: Limited Challenges to State Sovereignty' (2019) 64 International Studies Quarterly 1, 10.

21 ibid.

22 Energy Charter Secretariat (n 18) 30.

23 Fortum, 'Why Uniper?' (Fortum) <https://www.fortum.com/about-us/uniper/why-uniper> 9 November 2020. 
This point should also be prefaced with a note on the Achmea judgment of the Court of Justice of the European Union ('CJEU'). ${ }^{24}$ The ruling concerned an arbitral award rendered on the basis of the Netherlands-Slovakia BIT.

Put very briefly, the CJEU ruled that the arbitration clause of the BIT conflicted with the Treaty on the Functioning of the European Union ('TFEU'). Indeed, according to article 344 TFEU, 'Member States undertake not to submit a dispute concerning the interpretation or application of the Treaties to any method of settlement other than those provided for in the Treaties'. ${ }^{25}$ Since the arbitral tribunal would technically be empowered under the arbitration clause to interpret EU Law, this would conflict with article 344. Next, article 267 concerns the jurisdiction of the CJEU to give preliminary rulings on matters of EU law referred to it by a 'court or tribunal of a Member State'. ${ }^{26}$ Put very simply, since the arbitral tribunal does not have any formal link to the judicial system of an EU Member State, it does not constitute a 'court or tribunal of a Member State. ${ }^{27}$

This ruling effectively sounded the death knell for intra-EU BIT's. However, whether the Achmea judgment has similar implications with regard to dispute settlement under the ECT is less clear. Thus, recently, Belgium asked the CJEU for 'an opinion on the compatibility of the intra-European application of the arbitration provisions of the future modernised Energy Charter Treaty with the European Treaties. ${ }^{28}$ This point is undoubtedly beyond the remits of this paper. However, it suffices to say that whatever CJEU chooses to pronounce on this issue is likely to have significant implications on the arguments put forward in this paper.

Now, in any event, Lawyers Van den Berghe and Jolie have written a brilliant legal opinion dissecting Uniper's potential legal claims. ${ }^{29}$ Based on statements made by representatives of Uniper, it appears that the company is alleging breaches of the Fair and Equitable Treatment-standard ('FET'), as well as an indirect expropriation of its investment. ${ }^{30}$ The report provides a succinct analysis of the weaknesses of Uniper's arguments, and the author encourages all interested readers to go through the document themselves. For the purposes of this paper, a short summary of Uniper's legal arguments, and the authors' counterarguments, will suffice.

24 Case C-284/16 Slowakische Republik (Slovak Republic) v Achmea BV [2018] ECLI:EU:C:2018:158.

ibid para 32.

26 ibid paras $43-46$.

27 ibid para 47.

28 Kingdom of Belgium, Foreign Affair, Foreign Trade and Development Cooperation, 'Belgium requests an opinion on the intra-European application of the arbitration provisions of the future modernised Energy Charter Treaty' (Diplomatie.belgium.be, 3 December 2020) < https://diplomatie.belgium.be/en/newsroom/news/2020/belgium_requests_opinion_intra_european_ application_arbitration_provisions $>$ accessed 13 December 2020; See also Matthew Happold, 'Belgium asks European Court of Justice to opine on compatibility of Energy Charter Treaty's investor-State arbitration provisions with EU law' (EJIL:Talk!, 8 December 2020) <https://www.ejiltalk.org/belgiumasks-european-court-of-justice-to-opine-on-compatibility-of-energy-charter-treatys-investor-statearbitration-provisions-with-eu-law/> accessed 9 December 2020.

29 Van den Berghe and Jolie (n 10).

30 ibid 2. 


\section{A. Indirect Expropriation}

One of Uniper's arguments concerns indirect expropriation. ${ }^{31}$ Under a regular expropriation, a State directly takes control of an investor's property. In contrast, under an indirect expropriation, a measure or series of measures taken by the State lead to a substantial loss in the value and profitability of an investment. ${ }^{32}$ Intent need not be present. ${ }^{33}$ Under ECT article 13, the notion of an indirect expropriation is expressed in the phrase 'measure or measures having effect equivalent to nationalization or expropriation. ${ }^{34}$ If an expropriation takes place, compensation must be provided for the investor. ${ }^{35}$ Thus, Uniper's first potential argument is that, through the coal phase out plan, the Dutch government is substantially depriving its investment of value, which results is an indirect expropriation.

In response to this argument, the authors draw the essential distinction between non-compensable regulation and indirect expropriation. Indeed, under customary international law, it is well established that if a regulation is taken 'for a public purpose, carried out in a non-discriminatory manner and in accordance with due process of law', no compensation needs to be paid. ${ }^{36}$ This is sometimes referred to as the 'police powers' doctrine, which recognises that 'state measures that are prima facie lawful exercises of the government's powers... may affect foreign interests considerably without amounting to expropriation. ${ }^{37}$

However, the distinction between non-compensable regulation and expropriation is not black and white. David Khachvani rightly points out the marked dilemma here. On one hand, creating 'an unqualified exception from the duty of compensation for all legitimate regulatory measures would hardly be compatible with the language of the nonexpropriation' ${ }^{38}$ However, equally, 'encumbering all regulatory changes with the duty of compensation would be unduly burdensome on States' sovereignty and might induce a so-called regulatory chill.'

Having said that, one could certainly argue that, in the present case, the situation is much clearer: the Netherlands, a low-lying country that faces severe risks from elevated sea levels, needs to act quickly to mitigate climate change's effects. ${ }^{39}$ If anything, this is precisely the situation where a State should be as unencumbered as possible by ISDS threats. Consequently, to summarise the authors' arguments; the coal phase out plan is for a very valid public purpose,${ }^{40}$ and is non-discriminatory because the plan applies to all coal power plants. ${ }^{41}$

The last criterion of due process may be more difficult to discern in some instances. As put by Kotuby, '[e]very state has vastly different procedures to determine

\footnotetext{
31 'Uniper and its main shareholder Fortum have argued that Uniper was being "de facto expropriated without compensation"'; See Van den Berghe and Jolie (n 10) 5.

32 Robert Sloane, 'Indirect Expropriation and its Valuation in the BIT Generation' (2004) 74 The British Yearbook of International Law 115, 119.

33 ibid 120.

34 ECT (n 4) art 13(1).

35 ibid.

36 David Khachvani, 'Non-Compensable Regulation versus Regulatory Expropriation: Are Climate Change Regulations Compensable?' (2020) ICSID Review Foreign Investment Law Journal 1, 2.

37 Prabhash Ranjan, 'Police Powers, Indirect Expropriation in International Investment Law, and Article 31(3)(c) of the VCLT: A Critique of Philip Morris v. Uruguay' (2019) 9 Asian Journal of International Law 98, 103.

38 Khachvani (n 36) 2.

39 Van den Berghe and Jolie (n 10) 8.

40 ibid 7-8.

41 ibid 9 .
} 
what is "justice," and those procedures produce vastly different final judgments. ${ }^{42}$ However, for the purposes of this paper, the author believes that Hovell's elaboration on the instrumentalist model of due process suffices:

The model imagines a system based on clear and determinate standards, in which decision makers apply those standards rather than their own personal notions of fairness, justice, or appropriateness. The resulting decisions are amenable, in turn, to review by a judicial arbiter to determine whether the decisions can be counted as correct or incorrect. ${ }^{43}$

Indeed, in light of this elaboration, interpreting the due process criterion does not pose any significant problems. Here, Van den Berghe and Jolie's point is worth repeating at length:

Not only is the legislative proposal a good faith initiative to address a generally recognized fundamental issue of general interest. In addition, the issue is being handled according to the highest standards of legislative decisions-making as embodied in the legal system of the Netherlands. ${ }^{44}$

Now, to play the devil's advocate for a moment, one counter-argument that could be raised is that ECT's Article 13 directly replicates the wording of the police powers doctrine, with the exception that compensation is required even if the measure being taken for a public purpose, is non-discriminatory, and is in line with due process. ${ }^{45}$ Thus, applying the maxim lex specialis derogat legi generalis could lead to the conclusion that the ECT requires that compensation be paid to investors for all government regulations that have the 'effect equivalent to an expropriation'. ${ }^{46}$ Even if there was a general customary international law which provided that non-compensable regulation exists (and there is), the ECT's expropriation provision, which could be interpreted as the lex specialis, appears to always require compensation. The Energy Charter Secretariat recognised the complexity of the situation in its 2012 report on the 'Expropriation Regime under the Energy Charter Treaty', stating that:

The notion that the exercise of a state's "police powers" under international law will not give rise to a right of compensation is well established. The position in the realm of investment treaty arbitration is less certain because of the broad formulation of the expropriation provision in investment treaties, including most BITs and the ECT. ${ }^{47}$

When faced with a similarly worded article on expropriation as the ECT, the Philip Morris $v$ Uruguay Tribunal employed Article 31(3)(c) of the Vienna Convention on the

42 Charles T Kotuby, 'General Principles of Law, International Due Process, and The Modern Role of Private International Law' (2013) 23 Duke Journal of Comparative \& International Law 411, 424.

43 Devika Hovell, 'Due Process in the United Nations' (2016) 110 Asian Journal of International Law 1, 5-6.

44 ibid 9-10.

45 ECT (n 4) art 13.

46 ibid.

47 Energy Charter Secretariat, 'Expropriation Regime under the Energy Charter Treaty' (Energy Charter Secretariat 2012) 36. 
Law of Treaties ('VCLT'), which obliges the treaty interpreter to take into account '[a]ny relevant rules of international law applicable in the relations between the parties', which is understood to include customary international law. ${ }^{48}$ Thus, the police powers doctrine was incorporated from customary international law to decide that Uruguay's tobacco plain packaging law did not constitute an indirect expropriation of the Claimant's trademarks. ${ }^{49}$ Furthermore, regarding the interaction between treaties and customary international law, an important statement by the ICJ is also worth keeping in mind:

...even if a treaty norm and a customary norm relevant to the present dispute were to have exactly the same content, this would not be a reason for the Court to take the view that the operation of the treaty process must necessarily deprive the customary norm of its separate applicability. ${ }^{50}$

Of course, the treaty and custom being discussed by the ICJ are not the same as in the present case. However, even in the context of the Uniper dispute, it offers food for thought.

All in all, the point that the author has been attempting to put forward which is that the distinction between non-compensable regulation and indirect expropriation under the ECT regime, remains a rather complicated affair.

The authors make an interesting final point on the matter. Even if, hypothetically, the Dutch government's actions would not constitute a non-compensable regulation, it would still not constitute an indirect expropriation. This is because the measure would need to result in a 'substantial deprivation' of the investment value. ${ }^{51}$ This is also known as the 'sole effects' doctrine. As put by Mostafa, it is argued by some that there is a threshold beyond which 'a finding of expropriation is unavoidable. ${ }^{52}$ This threshold is surpassed when, for instance, "the measure "removes all benefits of ownership", "renders property "virtually valueless"', or 'become[s] equivalent to the [direct] expropriation of a property right'. ${ }^{53}$ Thus, on this point, the authors' analysis suggests that the Maasvlakte power plant would likely not have much market value in any situation after 2030 due to 'evolving market conditions [in the energy sector] and the poor investment decision made in 2007-2008' ${ }^{54}$ Furthermore, it does not necessarily remove all benefits of ownership, since 'the proposed law does not require Uniper to close but allows it to convert to noncoal-fired production. ${ }^{55}$ Whilst this is a very interesting point, it is also a rather factually intensive question that begs for an entire paper of its own. However, what remains clear is that deciding on Uniper's expropriation claim would be no easy task for any Tribunal.

48 Vienna Convention on the Law of Treaties (adopted 23 May 1969, entered into force 27 January 1980) 1155 UNTS 331 (VCLT) art 31(3)(c); Case Concerning Oil Platforms (Islamic Republic of Iran v United States of America) (Judgment) [2003] ICJ Rep 161 [42].

49 Philip Morris Brands Sàrl, Philip Morris Products SA and Abal Hermanos SA v Oriental Republic of Uruguay (Award 2016) ICSID Case No ARB/10/7 (Philip Morris v Uruguay) [290-301], [307].

50 Case Concerning Military and Paramilitary Activities in and Against Nicaragua (Nicaragua $v$ United States of America) (Judgment) [1986] ICJ Rep 14 [175].

51 Van den Berghe and Jolie (n 10) 12.

52 Ben Mostafa, 'The Sole Effects Doctrine, Police Powers and Indirect Expropriation under International Law' (2008) 15 Australian International Law Journal 267, 279.

53 ibid 279-280.

54 Van den Berghe and Jolie (n 10) 14.

55 ibid 13 . 


\section{B. Fair and Equitable Treatment}

The second alleged breach concerns the FET standard under article 10(1) of the ECT. ${ }^{56}$ Under the FET standard, the ECT contracting parties promise to, inter alia, 'encourage and create stable, equitable, favourable and transparent conditions for Investors of other contracting parties to make investments in its area' and 'observe any obligations it has entered into with an Investor or an Investment of an Investor of any other Contracting Party. ${ }^{57}$ Central to the FET-standard is the concept of legitimate expectations. Put briefly, the latter concept concerns situations where a State has made specific commitments and representations on which the investor relies on when making the investment. ${ }^{58}$ If the expectation created by the State is frustrated, then the investor has reasonable grounds to allege a breach of the FET-standard.

Here, the authors point out that 'no promises were made or guarantees were given to Uniper' and 'international norms do not guarantee that legislation will remain unchanged'. Lastly, the coal phase out plan is certainly not arbitrary or non-transparent, as it is in line with what any highly polluting company, including Uniper, should have been well-aware of in light of the global, regional and national measures being taken against climate change. ${ }^{59}$ The authors cite a statement of the Philip Morris that is worth repeating here analogously: 'Manufacturers and distributors of harmful products such as cigarettes can have no expectation that new and more onerous regulations will not be imposed'. ${ }^{60}$

Thus, in summary, the authors' statement that Uniper's potential claims are 'legally misconceived' is not far from the truth. However, it is also clear that, in the words of Niemelä and others, 'its arguments are non-frivolous and have some legal merit in light of the basic principles of international investment law. ${ }^{61}$ To illustrate this point, the author will continue with some comments about the EU's modernisation proposal, and the content of the proposed articles on frivolous claims.

\section{The European Union's Proposal: Steps in the Right Direction}

Before delving into the EU's proposal, the author would like to stress the point that, by and large, the proposals made therein are significant steps in the right direction. It should also be mentioned that many of the EU's suggestions are taken directly from its Comprehensive Economic and Trade Agreement ('CETA') with Canada. ${ }^{62}$ This is particularly with regards to suggested clarifications on the contents of the FET, the definition of expropriation, and the express recognition of States' right to regulate. ${ }^{63}$

Moreover, the point here is not to argue that a provision on frivolous claims will be ipso facto ineffective, but instead to show that, based on the current state of jurisprudence on frivolous claims, the proposed article in the ECT is unlikely to be useful

56 ECT (n 4) art 10(1).

57 ibid.

58 Trevor Zeyl, 'Charting the Wrong Course: The Doctrine of Legitimate Expectations in Investment Treaty Law' (2011) 49 Alberta Law Review 203, 207.

59 Van den Berghe and Jolie (n 10) 18-19.

${ }^{60}$ Philip Morris v Uruguay (n 39) [429-430], quoted in Van den Berghe and Jolie (n 10) 16.

61 Niemelä and others (n 8).

62 Comprehensive Economic and Trade Agreement (adopted 30 October 2016, provisional application 21 September 2017) (CETA) arts 8.9-8.45<https://ec.europa.eu/trade/policy/in-focus/ceta/ceta-chapterby-chapter/> accessed 9 November 2020.

63 Commission (n 14) 4-8. 
against the types of claims that Georgia, and many other States, are concerned about. Thus, next, the author would like to draw the reader's attention to the EU's proposed articles that are likely to be helpful when States begin to make more robust environmental regulation.

\section{A. Clarifying the Content of the FET-standard}

To begin with, the proposal provides a much more comprehensive overview of what the notoriously ambiguous FET standard includes. Thus, the ECT's previous verbose article has been separated into a number of more appropriate, legally digestible parts. In the proposed Article 1(i) a number of clear breaches of the FET standard, such as denial of justice and fundamental breach of due process, are listed. ${ }^{64}$ Then, in Article 1(ii) the concept of legitimate expectations is expressly laid out, more specifically whether the contracting party 'made a specific representation to an investor to induce a covered investment'. ${ }^{65}$ Evidently, however, the ambiguity of what 'specific representations' entails is still very much present, and is likely to be a factually intensive process in most cases.

\section{B. Distinguishing Non-compensable Regulation from Indirect Expropriation}

Perhaps most importantly for the Uniper situation, there is an entirely new suggested Article on 'Regulatory Measures', which, similar to CETA, highlights the right of contracting parties to regulate within their territories to achieve 'legitimate policy objectives,' obviously including 'the protection of the environment' ${ }^{66}$ This point is restated in Annex X of the proposed article on expropriation, in which it is provided that in most circumstances, the protection of legitimate policy objectives that result in investor losses will not constitute an indirect expropriation. ${ }^{67}$ Thus, the proposed articles would directly address Uniper-like claims for compensation. Now, having outlined the amended FET and expropriation provisions, it is most importantly worth exploring the proposed article on frivolous claims.

\section{Frivolous Claims: Combining Two Different Models}

To begin with, the first paragraph of the EU's proposed article on frivolous claims is largely based on ICSID Arbitration Rule 41(5), which allows a party in an ICSID proceeding to 'file an objection that a claim is manifestly without legal merit. ${ }^{168}$ This objection must be raised 'no later than 30 days after the constitution of the Tribunal, and in any event before the first session of the Tribunal' ${ }^{69}$ If the Tribunal finds that one or more of the claims are 'manifestly without legal merit' it must 'render an award to that effect' under Rule 41(6). ${ }^{70}$ Admittedly, the procedural details of the EU's provision, such as the time limits, are slightly different. However, the key phrase 'manifestly without legal merit' remains untouched.

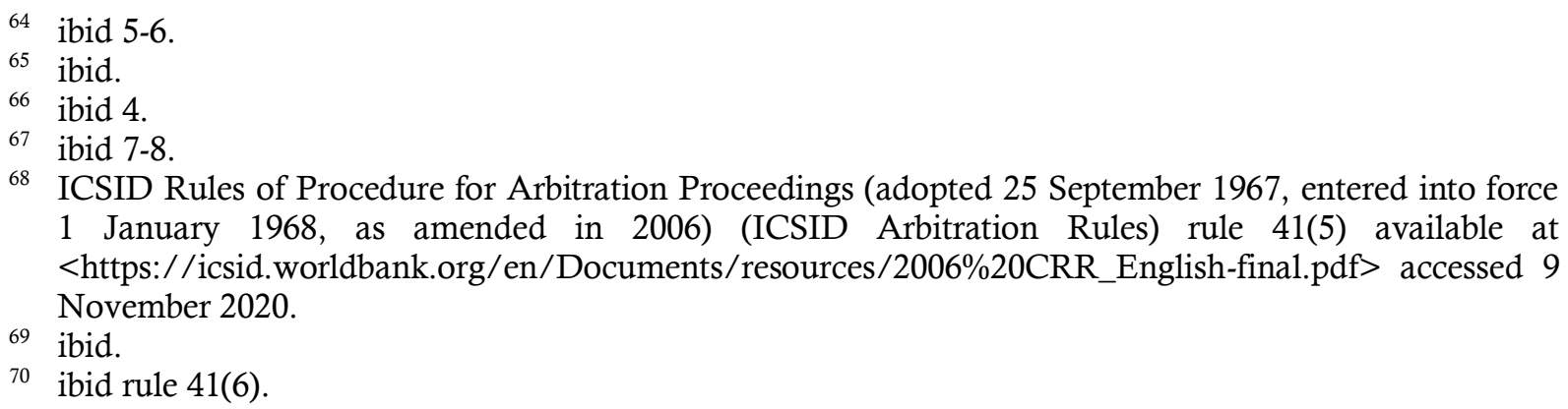


The second paragraph, instead of referring to a case that is 'manifestly without legal merit', speaks of a preliminary objection against 'a claim for which an award in favour of the Investor [cannot] be made. ${ }^{71}$ Such a provision is also found in CETA and DR-CAFTA. ${ }^{72}$ Although jurisprudence on such claims is much more limited compared to Rule 41(5), some remarks are worth making.

As shown by Polonskaya, this formula first appeared in United States ('US') BITs following its long and tedious experience in Methanex $v U S,{ }^{73}$ in which the US argued that the Claimant lacked legally viable claims. ${ }^{74}$ Without a mechanism to counter such claims, the US amended its Model BIT to allow subsequent Tribunals to dismiss legally unmeritorious claims. ${ }^{75}$ Since then it has been repeated in a number of other treaties, such as DR-CAFTA. ${ }^{76}$ Polonskaya points out that this is a much broader standard than Rule 41(5). ${ }^{77}$ Overall, she summarises the approach of Tribunals faced with the same situation as a 'I know it when I see it', and that they have 'failed to articulate the applicable standard of scrutiny explicitly'. ${ }^{78}$ This is in stark contrast to the ICSID standard, which has almost been fleshed out too explicitly, as will be shown later. Nevertheless, it appears that Tribunals faced with the second formulation for frivolous claims have been rather hesitant to interpret the provision too broadly. ${ }^{79}$ Consider the following extracts from the Pac Rim v El Salvador arbitration.

Firstly, a 'tribunal must have reached a position, both as to all relevant questions of law and all relevant alleged or undisputed facts'. Furthermore, '[d]pending the particular circumstances of each case, there are many reasons why a tribunal might reasonably decide not to exercise such a power against a claimant, even where it considered that such a claim appeared likely (but not certain) to fail if assessed only at the time of the preliminary objection' ${ }^{80}$ Thus, the Tribunal is evidently treading very carefully about what kinds of claims it dismisses.

Furthermore, as stated previously, CETA has adopted such a provision as well, and article 8.33 provides that a claim may be preliminarily dismissed if 'as a matter of law... [the claim] is not a claim for which an award in favour of the claimant may be made'. ${ }^{81}$ Admittedly, one benefit of the CETA/DR-CAFTA provision is that, due to its broad formulation, it offers considerably more leeway on what kinds of claims the

71 Commission (n 14) 16-17.

72 CETA (n 62) art 8.33.

73 Ksenia Polonskaya, 'Frivolous Claims in the International Investment Regime: How CETA Expands the Range of Frivolous Claims That May Be Curtailed in an Expedient Fashion' (2017) 17 Asper Review of International Business \& Trade Law 1, 6.

74 Michele Potestà and Marija Sobat, 'Frivolous Claims in International Adjudication: A Study of ICSID Rule 41(5) And of Procedures of Other Courts And Tribunals To Dismiss Claims Summarily' (2012) 3 Journal of International Dispute Settlement 137, 164.

75 Edward G Kehoe, 'Motions to Dismiss in International Treaty Arbitrations', in Arthur W Rovine (Ed.), Contemporary Issues in International Arbitration and Mediation: The Fordham Papers 2015 (Brill Nijhoff 2016) 90.

76 Dominican Republic-Central America Free Trade Agreement (adopted 5 August 2004, entered into force 1 January 2009) art 10.20.4 (DR-CAFTA); Polonskaya, 'Frivolous Claims' (n 73) 6.

77 Ksenia Polonskaya, 'Frivolous and Abuse of Process Claims in Investor-State Arbitration: Can Rules on Cost Allocation Become a Solution?' (2020) Journal of International Dispute Settlement 1, 7.

78 ibid.

79 ibid.

80 Pac Rim Cayman LLC v Republic of El Salvador (Decision on the Respondent's Preliminary Objections Under CAFTA Articles 10.20.4 and 10.20.5, 2010) ICSID Case No ARB/09/12 [110-112] (Pac Rim v El Salvador).

81 CETA (n 62) art 8.33. 
Tribunal will allow. Polonskaya makes an interesting point that, combined with CETA's system for a more permanent investment court system, and its appellate mechanism:

CETA tribunals will have an opportunity to see at an early stage whether a claim is viable. This effect has long-term benefits for both states and investors. For example, foreign investors will know and understand the parameters of viable claims, which will help guide decisions and actions in investment proceedings. ${ }^{82}$

In other words, when (and if) CETA Tribunals become operational, they will be able to establish a much more consistent line of jurisprudence on frivolous claims that will hopefully positively re-enforce the right of states to regulate on environmental matters. The unfortunate obverse of this, of course, is that, in the more ordinary circumstances of ISDS, with no formal system of stare decisis or appeal, there is no impetus for Tribunals interpreting the modernised ECT to establish a consistent line of jurisprudence, no matter how desirable this may be.

The only caveat to this is that, in the EU's proposal, there is also a push for the establishment of a multilateral investment court with an appellate mechanism. ${ }^{83}$ The EU has added a clause in ECT Article 26 on dispute settlement which stipulates that:

For greater certainty, if the contracting party which is party to the dispute and the contracting party of the Investor have both consented to the jurisdiction of the multilateral investment court, the dispute under subparagraph 2(c) shall be submitted for resolution to such a multilateral court to the exclusion of the other mechanisms of dispute resolution referred to in paragraphs (4)(a) to (c) ${ }^{84}$

This would, ideally, remedy some of the concerns about consistency. Yet, although the author commends the EU for such an effort to reform the ISDS system, the idea has its discontents. Even the comparatively easier task of modernising the ECT has significant hindrances. Most notably, Japan 'believes that it is not necessary to amend the current ECT provisions. ${ }^{185}$ Given the requirement of unanimity for amending of the ECT under Article 36(1)(a), modernising it may be a nearly impossible task. ${ }^{86}$

Be that as it may, for the moment, the paucity of cases on DR-CAFTA-type provisions means that it is difficult to draw definite conclusions about its potential effectiveness in combating Uniper-like claims. Evidently, the relative broadness of the standard, in comparison to the first paragraph, gives hope that the provision will be more useful in the curtailment of opportunistic claims arising from environmental regulation.

Having elaborated on the EU's proposal, this paper will now turn its focus on ICSID Arbitration Rule 41(5). Then, based on the analysis of existing jurisprudence on the Rule, some conclusions will be drawn about the effectiveness of the suggested provisions on frivolous claims.

82 Polonskaya (n 73) 33.

Commission (n 14) 15-16.

84 ibid.

85 Climate Home News 'Japan Blocks Green Reform to Major Investment Treaty' (Climate Home News, 8 September 2020) <https://www.climatechangenews.com/2020/09/08/japan-blocks-green-reformmajor-energy-investment-treaty> accessed 9 November 2020.

86 ECT (n 4) art 36(1)(a). 


\section{ICSID Arbitration Rule 41(5)}

As was mentioned previously, Rule 41(5) concerns cases that are alleged to be 'manifestly without legal merit' ${ }^{87}$ Following the addition of the Rule in 2006, it has been used on 34 occasions, making it a relatively rare occurrence. ${ }^{88}$ What is further unfortunate is that only 17 of these cases are public. In the context of this paper, it is especially frustrating that the Rule 41(5) objection in the Vattenfall $v$ Germany ECT arbitration remains confidential. Alas, it would undoubtedly shed crucial light on what kinds of claims are permissible under the ECT. After all, the case is in some ways analogous to the Uniper situation, as it concerns Germany's nuclear phase out law and its effects on Vattenfall's nuclear power plants.

Nonetheless, Tribunals interpreting Rule 41(5) have made it clear that the range of cases which can be summarily dismissed is rather narrow. In the next sections, the author would like to explain why this is the case, and what implications this has for frivolous claims under the ECT.

\section{A. The High Standard for Rule 41(5)}

In spite of some divergences in the application of the Rule, the analysis of which is beyond the remits of this paper, ${ }^{89}$ Tribunals interpreting Rule 41(5) have set a consistently high threshold for a claim to be 'manifestly without legal merit'. Indeed, the first Tribunal interpreting the Rule in Trans-Global v Jordan laid out the parameters of the phrase in such a succinct, convincing manner that its approach has been followed by virtually all subsequent Tribunals applying the Rule.

The case concerns a US-based investor, TGPJ, who, upon the discovery of oil deposits in Jordan, alleged that Jordan 'began a systematic campaign to destroy the Claimant's investment' ${ }^{90}$ This campaign included, inter alia, 'pressuring TGPJ to assign a majority of its rights' to a Lebanese Company with 'no experience in oil exploration drilling', who subsequently failed to respect various contractual obligations ${ }^{91}$ Regarding the standard for Rule 41(5), the Tribunal determined that the objection must be established 'clearly and obviously with relative ease and despatch'. ${ }^{92}$ This criteria of obviousness and clarity has been endorsed expressly by the majority of subsequent Tribunals. ${ }^{93}$ Indeed, between Tribunals and commentators alike, there is a consensus that

87 ICSID Arbitration Rules (n 15) art 41(5).

88 ICSID, 'Decisions on Manifest Lack of Legal Merit' (ICSID 2020) $<$ https://icsid.worldbank.org/cases/content/tables-of-decisions/manifest-lack-of-legal-merit> accessed 9 November 2020; See also Lotus Holding Anonim Şirketi v. Turkmenistan (Award, 2020) ICSID Case No $\mathrm{ARB} / 17 / 30$ (Lotus $v$ Turkmenistan).

89 Oskari Vaaranmaa, 'To what extent has a jurisprudence constante emerged on the phrase "manifestly without legal merit" under ICSID Arbitration Rule 41(5)?' (LLM thesis, University of Groningen 2020).

90 Trans-Global Petroleum, Inc $v$ The Hashemite Kingdom of Jordan (Tribunal's Decision on the Respondent's Objection under Rule 41(5) of the ICSID Arbitration Rules, 2008) ICSID Case No ARB/07/25 [12] (Trans-Global v Jordan).

91 ibid [59], [68-69].

92 ibid [88].

93 Brandes Investment Partners, LP v The Bolivarian Republic of Venezuela (Decision on the Respondent's Objection under Rule 41(5) of the ICSID Arbitration Rules, 2009) ICSID Case No ARB/08/3 [63] (Brandes v Venezuela); Global Trading Resource Corp and Globex International, Inc v Ukraine (Award, 2010) ICSID Case No ARB/09/11 [35] (Global Trading v Ukraine); Rachel S Grynberg, Stephen M Grynberg, Miriam Z Grynberg, and RSM Production Corporation v Grenada (Award, 2010) ICSID Case No ARB/10/6 [6.1.1-6.1.3] (Rachel S Grynberg v Grenada); PNG Sustainable Development Program Ltd v Independent State of Papua New Guinea (Decision on Respondent's Objections under Rule 41(5), 2014) ICSID Case No 
Rule 41(5) will only apply to genuinely poor legal arguments. ${ }^{94}$ For instance, in the TransGlobal v Jordan case, only the last of three claims was dismissed because it was based on a fundamentally weak argument that the obligation to consult between the US and Jordan required Jordan to consult with the investor as well..$^{95}$ This argument could be dismissed simply by reference to the ordinary meaning of the terms in the BIT.

However, the bar has only been raised after the Trans-Global Tribunal's deliberation. This is particularly with regard to the (in)applicability of the Rule to 'resolve novel, difficult or disputed legal issues' ${ }^{96}$ Indeed, the general trend of jurisprudence around this issue is a converging one.

\section{B. 'Novel, Difficult or Disputed Legal Issues': Setting the Bar Too High?}

Whilst the Trans-Global Tribunal began by setting a rather high standard for a successful Rule 41(5) objection, subsequent Tribunals have only made it higher. This marked shift took place most clearly in the MOL v Croatia and PNGSDP v Papua New Guinea cases, and a similar approach has been either expressly endorsed, or echoed by most subsequent Tribunals. $^{97}$

To begin with, although in general agreement with the high standard set in TransGlobal, the MOL Tribunal is 'less convinced' about the former's interpretation that 'successive rounds of written and oral submissions' may be required to settle an objection. In its view, such interpretation would 'be carrying the tribunal into hybrid territory somewhere between Rule 41(5) and Rule 41(1). ${ }^{98}$ In the opinion of the $M O L$ Tribunal, there needs to be a distinction between cases that can be 'rejected out of hand' in contrast to those 'which [require] more elaborate argument' ${ }^{99}$ In other words, claims which reach an unspecified degree of legal complexity are not suitable for Rule 41(5).

A similar approach is endorsed in PNGSDP v Papua New Guinea. The case concerns an investor, PNGSDP, who is a stakeholder in a mining company, OTML, in Papua New Guinea. ${ }^{100}$ In 2001, '[a former shareholder] transferred all of its ordinary shares in OTML to the Claimant,' with the condition that the 'earnings from the mine

ARB/13/33 [88] (PNGSDP v Papua New Guinea); MOL Hungarian Oil and Gas Company Plc v Republic of Croatia (Decision on Respondent's Application Under ICSID Arbitration Rule 41(5), 2014) ICSID Case No ARB/13/32 [25], [45] (MOL v Croatia); Álvarez y Marín Corporación SA and others v. Republic of Panama (Reasoning of the Decision on Respondent's Preliminary Objections pursuant to ICSID Arbitration Rule 41(5), 2016) ICSID Case No ARB/15/14 [44] (Álvarez v Panama); Ansung Housing Co, Ltd v People's Republic of China (Award, 2017) ICSID Case No ARB/14/25 [70] (Ansung v China); Almasryia for Operating \& Maintaining Touristic Construction Co LLC v State of Kuwait (Award on the Respondent's Application under Rule 41(5) of the ICSID Arbitration Rules, 2019) ICSID Case No ARB/18/2 [29-31] (Almasryia v Kuwait); Lion Mexico Consolidated LP v United Mexican States (Decision on the Respondent's Preliminary Objection under Article 45(6) of the ICSID Arbitration (Additional Facility) Rules, 2016) ICSID Case ARB(AF)/15/2 [63] (Lion v Mexico); Elsamex, SA v Republic of Honduras (Decision on Elsamex S.A.'s Preliminary Objections, 2014) ICSID Case No ARB/09/4 [103] (Elsamex $v$ Honduras); Eskosol S.pA in liquidazione $v$ Italian Republic (Decision on Respondent's Application Under Rule 41(5), 2017) ICSID Case No ARB/15/50 [39-41] (Eskosol v Italy).

94 Sergio Puig and Chester Brown, 'The Power of ICSID Tribunals to Dismiss Proceedings Summarily: An Analysis of Rule 41(5) of the ICSID Arbitration Rules' (2011) 10 Law and Practice of International Courts and Tribunals 227, 255.

95 Trans-Global v Jordan (n 90) [118].

96 PNGSDP v Papua New Guinea (n 93) [89].

97 See Eskosol v Italy (n 93) [41]; Lion v Mexico (n 93) [66]; Almasryia v Kuwait (n 93) [32]; Lotus $v$ Turkmenistan (n 93) [158-160].

98 MOL v Croatia (n 93) [45].

99 ibid.

100 PNGSDP v Papua New Guinea (n 93) 17. 
were used to promote sustainable development within PNG and advance the general welfare of the people of PNG'. ${ }^{101}$ Thus, in 2011, the Claimant held $63.4 \%$ of OTML's shares. ${ }^{102}$ However, through the 2013 Mining Act, Papua New Guinea declared that 'all ordinary shares held by PNGSDP in the share capital of OTML shall be cancelled and cease to exist'. ${ }^{103}$ The Claimant, then, alleged that Papua New Guinea's actions constituted, among other violations, an unlawful expropriation. ${ }^{104}$

In raising the Rule 41(5) objection, Papua New Guinea asserted that it had not consented to arbitration, and that, since PNGSDP's purpose was 'sustainable development' and the 'general welfare of people,' 'there was no 'private foreign investment. ${ }^{105}$

As a general remark, the Tribunal comments that the interpretations by prior ICSID tribunals' are 'highly relevant and material to its consideration of the Application. ${ }^{\prime 06}$ However, most importantly, the principal way by which the PNGSDP Tribunal tries to develop the interpretation of Rule 41(5) is by positing that it is not intended to resolve novel, difficult or disputed legal issues' ${ }^{107}$ Consequently, since the 'Respondent's objections concern, inter alia, the interpretation of both PNG's domestic legislation and the ICSID Convention [i.e. novel, difficult legal issues]... [it is not] appropriate for Resolution under Rule 41(5).' ${ }^{108}$ The interpretation is certainly not without its problems and controversies, as will be demonstrated below.

Firstly, it could certainly be argued that the PNGSDP Tribunal is severely restricting the chances that Rule 41(5) objections will succeed. In this respect Rosenfeld is right in pointing out that such an interpretation 'limits the potential to use ICSID Arbitration Rule 41(5) as a mechanism [for states] to reassert control [over the investment regime]. ${ }^{109}$ What Rosenfeld appears to be referring to is the intention of the States that created the Rule. This intention will be discussed in due course later in this paper.

The other glaring problem with the PNGSDP Tribunal's interpretation is what is meant by 'undisputed issues of law'. As stated by Polonskaya, 'in the context of investment arbitration, identifying "genuinely indisputable Rules of law" may be difficult, given the existing level of divergence with respect to the meaning of substantive standards of investment protection. ${ }^{110}$

However, it should be mentioned that, for the moment, the anticlimactic fact is that in the vast majority of instances where a Rule 41(5) objection has succeeded, the issue in question has been rather simple.

For example, in Rachel $S$ Grynberg $v$ Grenada, the primary issue concerned res judicata and the re-litigation of a prior arbitration by the same Claimants. ${ }^{111}$ Then, in Emmis and Accession, claims that were unrelated to expropriation were dismissed, since the Respondent Hungary had expressly not consented non-expropriation claims in the

\footnotetext{
101 ibid 19.

102 ibid.

103 ibid 25.

104 ibid 29.

105 ibid 31.

106 ibid 8.

107 ibid 89.

108 ibid 93.

109 Friedrich Rosenfeld, 'Early Dismissal of Claims in Investment Arbitration', in Andreas Kulick (ed.), Reassertion of Control over the Investment Treaty Regime (Cambridge University Press 2017) 92.

110 Ksenia Polonskaya, 'Frivolous and Abuse of Process' (n 77) 5.

111 Rachel S Grynberg v Grenada (n 93) 7.3.6-7.3.7.
} 
relevant BIT. ${ }^{112}$ In the case of Lotus $v$ Turkmenistan 'all of the claims set out in the Request for Arbitration are properly to be characterized as contract claims relating to contracts entered into by Lotus Enerji' and 'the contract claims are not claims of Lotus Holding' the Claimant in this instance. ${ }^{113}$

Thus, in the few cases that Rule 41(5) objections have succeeded, the issues have been undisputed, and the PNGSDP Tribunal's interpretation would not pose any problems. However, it is also for this reason why Howes, Stowell and Choi suggest that '[a] major contributing factor to the low observed success rate of ICSID Rule 41(5) applications, no doubt, is the reluctance of tribunals to determine complicated or novel questions of law'. ${ }^{114}$

Put differently, even if cases so far have been relatively easy to settle, this does not detract from the point that the strict interpretation adopted by the PNGSDP Tribunal effectively prevents more complicated, but still 'legally misconceived', arguments from being dismissed early. Interestingly enough, the Pac Rim $v$ El Salvador Tribunal, interpreting the previously mentioned article $10.20 .4-10.20 .5$ of the DR-CAFTA, also found that 'it should not ordinarily be necessary to address at length complex issues of law, still less legal issues dependent on complex questions of fact or mixed questions of law and fact.' 115

Ultimately, what the preceding analysis suggests is that the Rule 41(5) objection, and in many ways the DR-CAFTA formulation, will only succeed against genuinely hopeless legal claims. Such claims are not necessarily made by litigious investors who seek to threaten the host State, but are by and large just based on faulty legal reasoning. Having explained this, an interesting question comes to mind. Namely, did the ICSID contracting parties intend for the Rule to have a more robust protective ability?

\section{The intention behind Rule 41(5): protection against litigious investors?}

The author believes that there is a slight tension between what the intention of the ICSID contracting parties is and how Rule has been interpreted by Tribunals. Thus, whilst a full discussion on doctrine of treaty interpretation cannot be done, the author wishes to make a point on the intention of the parties. Indeed, there is some convincing evidence for supporting a more permissive interpretation of Rule 41(5). By 'permissive' the author means that a Tribunal is willing to engage with issues that might be, under a stricter Tribunal, too complex for a Rule 41(5) objection. So, what may the intention behind Rule 41(5) have been?

As mentioned previously, through an amendment in 2006, Rule 41(5) was included following 'recurring complaint' from governments. ${ }^{116}$ Its purpose was essentially to defend States against litigious investors. The first effort to counter frivolous claims arose from the US' experience in the Methanex arbitration. ${ }^{117}$ Indeed, it led the US to

112 Emmis International Holding, BV, Emmis Radio Operating, BV, MEM Magyar Electronic Media Kereskedelmi és Szolgáltató Kft v The Republic of Hungary (Decision on Respondent's Objection Under ICSID Arbitration Rule 41(5), 2013) ICSID Case No ARB/12/2, 85 (Emmis v Hungary).

113 ibid 195.

114 Ted Howes, Allison Stowell and William Choi, 'The Impact of Summary Disposition on International Arbitration: A Quantitative Analysis of ICSID'S Rule 41(5) On Its Tenth Anniversary' (2019) 13 Dispute Resolution International 7, 41.

115 Pac Rim v El Salvador (n 80) 112.

116 Antonio R Parra, 'The Development of the Regulations and Rules of the International Centre for Settlement of Investment Disputes. ICSIDRev' (2007) 22 ICSID Review Foreign Investment Law Journal 55, 65.

117 Potestà and Sobat (n 74) 164. 
amend its Model BIT to address legally unmeritorious claims. ${ }^{118}$ Consequently, as pointed out by former ICSID Deputy Secretary-General Antonio Parra, the 2006 amendment to the ICSID Arbitration Rules was '[i]nspired by the new [US] treaty provisions'. ${ }^{119}$ In other words, the amendment was enacted by the contracting states who were understandably eager to avoid facing Methanex-like arbitrations in the future. So, how can one view this from the angle of treaty interpretation?

As has now become evident, the author believes that a 'subjective approach' which 'seeks to investigate the actual intentions of the parties' provides appropriate guidance for the interpretation of the Rule. ${ }^{120}$ Indeed, a more permissive approach for applying the Rule would give it the degree of effectiveness that the contracting states intended. If the barrier for claims that can pass Rule 41(5) is lowered too much, this ultimately undermines its protective potential. At the moment, the objection can only be used to address a very narrow range of weak legal claims. Conversely, if the Claimant simply suggests a small degree of legal or factual complexity in its case, the objection will effectively be bypassed. In the cases where the objection has succeeded, the legal weaknesses of the claims have been as obvious a graduate student than they have been to experienced arbitrators. It seems rather improbable that the contracting states only wanted the Rule to be effective in situations where, for instance, the Claimant fails to initiate ISDS proceedings within a clearly specified limitation period. ${ }^{121}$ Such cases are evidently 'manifestly without legal merit', but are also far less harmful than cases where the investor is actually attempting to threaten the host State with claims that are sufficiently complex to defeat the Rule 41(5) objection, but ultimately bound to fail.

Of course, it also goes without saying that the Rule should not be utilised as a legal wall that sacrifices due process and investor rights. As is rightly noted by Arbitrator Dévaud in the Almasryia $v$ Kuwait case, the standard of the Rule has an inherent degree of strictness that clearly exists to protect the investors' due process rights. ${ }^{122}$ Chatterjee also recognises this in arguing that 'an enthusiastic Respondent must be treated cautiously'. ${ }^{123}$ However, all that is being argued here is that this difficult balance has perhaps been upset by a tipping towards the pro-investor end of the spectrum.

Having explained the jurisprudence on Rule 41(5), it is evident that Tribunals have set the bar for a successful objection very high. However, this also has some unfortunate implications for the effectiveness of the EU's proposed article against Uniper-like situations. This will be touched upon in the final section on concluding remarks.

\footnotetext{
118 Kehoe (n 75) 90.

119 Antonio R Parra, The History of ICSID (Oxford University Press 2012) 250.

${ }^{120}$ Francis G Jacobs, 'Varieties of Approach to Treaty Interpretation: With Special Reference to the Draft Convention on the Law of Treaties before the Vienna Diplomatic Conference' (1969) 18 International and Comparative Law Quarterly 318, 319.

121 As was the case in Ansung $v$ China.

122 Almasryia for Operating \& Maintaining Touristic Construction Co LLC v State of Kuwait (Dissenting Opinion on the Respondent's Application under Rule 41(5) of the ICSID Arbitration Rules, 2019) ICSID Case No ARB/18/2, [2], [5-6] (Dissenting Opinion of Arbitrator Dévaud).
}

${ }^{123}$ Charles Chatterjee, 'A Critical Examination of Rule 41(5) of the ICSID Arbitration Rules, 2006' (2012) 13 The Journal of World Investment \& Trade 486, 497. 


\section{Concluding Remarks: Too Weak to Succeed, but Not Frivolous Enough to Be Summarily Dismissed}

In summary, the general conclusion that can be drawn from the preceding analysis is that the currently proposed provisions on frivolous claims are unlikely to allow for Uniperlike cases to be summarily dismissed. That is unless Tribunals interpreting the modernised ECT make a conscious effort to broaden the provisions' applicability to more complex legal issues, and distance themselves from the past interpretations.

For example, determining whether legitimate expectations have been frustrated will remain a factually and legally complicated process. It is certainly not a novel legal issue, but it is definitely a difficult and disputed one. The same goes for the question of expropriation. Even when backed up by an express right to regulate, alleged expropriations need to be evaluated on a careful, fact-based, case-by-case basis. ${ }^{124}$ Thus, there is certainly still a risk that cases will become drawn-out. After all, so far, Rule 41(5) objections have by and large only succeeded against hopeless legal claims. Thus, considering the present state of jurisprudence on the Rule, Uniper-like claims are likely too complicated to be addressed on a summary basis.

Admittedly, clarified FET and expropriation standards, as well as express references to the States' right to regulate will ultimately lead to more arbitration victories for States. It is entirely possible that, over time, litigious investors will be discouraged from bringing claims against States for taking action against climate change. Ultimately, however, if the prevailing interpretation that Rule 41(5) should not apply to "novel, difficult or disputed legal issues' is adhered to, this significantly narrows down the types of claims on which the objection will succeed. ${ }^{125}$ The same goes for the DR-CAFTA-type provision.

Evidently, one positive fact is that the absence of stare decisis in investment arbitration entails that future Tribunals applying the (hopefully) modernised ECT will be free to interpret the provisions in a more permissive manner, if they so wish. For example, it is not completely inconceivable that, in light of the wider context, object and purpose of the modernised ECT, it would be acceptable to deal with Uniper-like cases through a summary procedure. In other words, when interpreted against provisions that directly reinforce States' right to regulate; the Uniper-like cases are immediately legally weakened to a significant degree. On the other hand, however, the relative consistency of interpretation around Rule 41(5) objections suggests that the subsequent Tribunals may feel compelled to chart the same course as their predecessors.

In any event, it remains safe to say that for the moment, future Uniper-like compensation demands for alleged ECT breaches are irresponsible - both legally and societally, but not frivolous enough. Whilst the future is certainly not hopeless with regards to ISDS and climate change, some sweeping reforms are direly needed.

*

\section{www.grojil.org}

\footnotetext{
124 This is also expressly stated in Annex X(2) of the EU's modernisation proposal; See Commission (n 14) annex $\mathrm{X}(2)$.

125 ibid 89.
} 